\title{
The Effects of Insider Ownership Capital Structure of Main
}

\section{Board Listed Companies}

\author{
Yeen Lai, Khong ${ }^{1 *}$, Peck Ling, Tee ${ }^{1} \&$ Mahendra Kumar a/l Chelliah ${ }^{1}$ \\ ${ }^{1}$ Faculty of Accountancy and Management, Universiti Tunku Abdul Rahman (UTAR), Kuala Lumpur, \\ Malaysia \\ *Yeen Lai, Khong, E-mail: khongyl@utar.edu.my
}

Received: January 1, 2017

Accepted: January 18, 2017 Online Published: January 22, 2017

doi:10.22158/rem.v2n1p43

URL: http://dx.doi.org/10.22158/rem.v2n1p43

\begin{abstract}
In this paper, researcher tends to discuss the "internal control protects shareholders from agency problem". The term of insider ownership refer to the shareholders who manage the company as well. In other words, the managers are also the owner of the company. Hence, the conflict of interest between the shareholders and managers will reduce as the higher on concentration insider ownership. In this study, insider ownership expressed as the percentage of the firm's outstanding share held by the insider. Insider ownership can be classified into outstanding share held by directors, director's family members (e.g., spouse and siblings), board members and employees'share option scheme committees. Family or insider groups as a significant shareholder is more likely to be interested in control benefit as well as profit and decision making (Teall, 2007). Small firms usually are higher in insider ownership than outsider control. When a firm expands the business through public listing, the ownership will distribute ownership opportunity to the public. In Malaysia, when go to public listing, the 30\% shares must hold by bumiputra. If there are non-bumiputra companies, the companies will gather $30 \%$ shares from outsiders who are bumiputra to meet the listing requirement.
\end{abstract}

\section{Keywords}

agency problem, conflict of interest, insider ownership, non-bumiputra companies, listing requirement

\section{Introduction}

\subsection{Background of the Study}

The research studies the effect of insider control on the capital structure. In this study, we investigate the relationship between the levels of concentration of the insider ownership and the capital structure decision of Malaysian main board listed companies.

Capital structure decision is one of the core determinants of firm value. It refers to the way of a firm rises their funds through some combinations of debt, equity or hybrid securities. This financing 
decision is called capital structure decision. If there is improper way to make capital structure decision, it will lead to agency cost, bankruptcy cost and asymmetric information. Therefore, capital structure decision is important to affect firm value.

The problems of corporate governance in transition and developing countries are usually the conflict of interest between the shareholders (principal) and agents (manager). This is called agency theory. An agency relationship arises whenever one or more individuals, called agents, to perform some service and then delegate the authority to agents for decision-making (Kleiman, 2006). The managers may have personal goal rather than maximize shareholder's wealth. They may not really act on behalf of the shareholders. This problem will cause to serious moral hazard problem. The agency cost would decrease the firm value. To ensure the interest of manager act in the favour of shareholders, the managers will be received the stocks and become shareholder as well. This will reduce separation of ownership control.

Ownership structure is a determinant for capital structure decision. A firm with higher insider ownership and higher outsider ownership would have different prospect to make capital structure decision. Another factor that affects capital structure is the firm size. Small firms would have more potential to grow compare to large firms. They are more willing to accept higher risk level than large firms. Therefore, firm size will also affect to the capital structure. The last factor that we will study is industry sector effect. A given industry will have similar leverage ratios while leverage ratios will vary across industries.

\subsection{Problem Statement}

In Huang and Song (2006) study, they had presented a series of determinants of capital structure, i.e., profitability, tangibility, tax, size, growth opportunities, volatility, and ownership structure. They examine all this factors in a developing country - China. Similarly, in our study we will look at the capital structure in Malaysia scenario, which is also a developing country with a debt to equity ratio slightly higher than Malaysia. However, further in depth study has to be conducted due to there are many different results from various researchers that study the insider ownership and capital structure relationship in different country.

Researchers such as Brailsford, Oliver and Pua (1999) found that there is curvilinear relationship between the level of managerial share ownership and leverage. In Wansley, Collins and Dutta (1996) research stated that there is nonlinear relationship between insider shareholdings and leverage. Besides that, Tse and Jia (2007) argued that insider shareholdings and major shareholdings on debt level are varied and depends on the level of leverage in their research.

According to Phani, Reddy, Ramachandran and Bhattacharyya (2002) had found that there is positive relationship between insider ownership and $\mathrm{D} / \mathrm{E}$ ratios in the firm with insider ownership greater or equal to $51 \%$ and vice versa. Other researchers such as Driffield, Mahambare and Pal (2005), and Pant, Manoj, Pattanayak and Manoranjan (2007) also proved the positive relationship between insider ownership and leverage. In contrast, Garcia and Olvera (2004) have argued that there is negative 
relationship between insider ownership and debt level. In addition, Huang and Song (2006) has found no relationship between insider ownership and capital structure in their study. There are many different views and theories found by researchers regarding the relationship between insider ownership and capital structure. However, such research towards Malaysia's firm is very rare. It would be a challenging task to investigate how is the relationship between insider ownership and capital structure of the firms in Malaysia with regards of the firm size and the industry of the firm.

\subsection{Research Question}

1) Does insider ownership affect capital structure decision?

2) Does firm size influence the relationship between insider ownership and capital structure?

3) Does sector in which firms operate influence the relationship between insider ownership and capital structure?

\subsection{Objectives of the Study}

Our main objective of conduct this research is to examine how insider ownership affects the capital structure of the company, which we will examine the relationship by analyse the Main Board public listed companies in Bursa Malaysia. Besides that, our specific objectives of the study is to investigate whether insider ownership affect capital structure decision differently in different sectors or different firm size categories. This study also aims to determine the distribution of insider control and capital structure in various sectors and firm size categories.

\subsection{Significant of the Study}

We study the effects of insider ownership on capital structure. Capital structure decision is important for managers and shareholders. However, the degree of insider ownership can imply the agency cost of the companies which will result the different capital structure decision. According to Braisford, Oliver and Pua (1999), the distribution of ownership among different groups can impact on managerial opportunism which subsequently can influence the managerial behaviour and corporate governance. Therefore, this study will benefit to the managers and shareholders in Malaysia in order understand the effect of insider ownership on capital structure decision.

\section{Literature Review}

According to Teall (2007) and Kleiman (2006), the agency problem arises when managers face a conflict of interest; their own personal objectives do not align with those of the shareholders whom they present. The managers who prefer cash compensation may require substantially more value in stock or other incentives in order to forego salary in favour of performance-based compensation. In particular, large firms will find that their shareholders have a wide variety of conflicting interest and opinion with the managers, eventually lead to higher agency cost. When there is higher agency costs, which are expenses incurred in order to maintain the relationship between principals and agents. The problem occurred because of the self-interested behaviour. Since the shareholders give power to managers to manage the firm's assets, a potential conflict of interest exist between the two groups. To 
reduce the agency cost, the ownership should be more insider than the outsider. Hence, to solid the power of shareholders, they would not prefer use equity for their capital decision in order to avoid dilution of control. There is a positive relationship between insider ownership and capital structure.

According to Brailsford, Oliver and Pua (1999), agency theory influences the relationship that exists between managers and shareholders of firms. In the study, the managerial approach to capital structure and the managerial self-interests hypothesis suggest that capital structure decisions are influenced by managers' adverse incentives and the incentive for managers to act opportunistically can be influenced by the structure of equity ownership. The increased monitoring by the insider holders increase the managerial opportunism and lead to higher agency conflicts. Thus, the firms with large insider ownership have significantly lower average of debt ratios.

Wansley, Collins and Dutta (1996) construct that the principal-agent relationship maintains that an increase of insider ownership reduces the agency cost of issuing debt. They suggest that the agency costs of debt increase significantly high levels of insider ownership, revealing a nonlinear relation attributable to agency costs. Debt financing relevant to agency cost framework because it reduces the insiders' behavioural conflict with outside equity holder. Therefore, higher level of insider ownership serves to more closely to align the interest of managers with those of outsiders as the debt rises. In the research, they found significant nonlinear relationship between the firm's debt level and its ownership structure.

The empirical result of Jensen and Meckling (1976) showed that the insider ownership has an important impact on managers' financial decision. They pointed out that the agency cost of debt exists as the firm shift to riskier investment after the firm issue debt, and transfer wealth from creditors to shareholders to exploit to the option nature of equity. Thus, when there is rising of the management ownership, the costs of pursuing a non-value maximizing objective decline. Besides, the optimal structure of leverage and ownership maybe used to minimize the agency costs. There are some expected correlation between ownership (including managerial ownership) structure and leverage. However, this study did not provide a clear relationship between insider ownership and capital structure.

\section{Research Methodology}

This study's sample selection criterion is based on secondary data from 652 listed companies on Main Board updated as at 31st December 2007 in Bursa Malaysia (KLSE). Firstly, we will exclude the minor sector which is less than 30 listed companies in one sector. This is due to the particular sector only consisting of few listed companies in Main Board and the sector size is too low, therefore we shall exclude it in our studies. Total deduction for the minor sectors is 31 companies which are under Hotels, Mining, Technology, REITS, Infrastructure Project Companies (IPC), Closed-end Fund and Exchange Trade Fund sectors.

Thus, this study employs the six industries in Main Board which are Consumer Products, Industrial 
Products, Construction, Trading and Services, Properties and Plantations. In addition, finance sector which consists of 41 companies will be excluded due to the difference in capital structure requirement with other companies in Main Board. The nature of the business of finance sector involved accepting deposits from depositors and act as lender to provide loans. Therefore, the capital structure of these companies is not appropriate to be including in this study because it will affect the veracity of our studies finding.

Second criteria of the sample selection are data employs in our sample size must consist of five years data from 2003 to 2007. Subsequently, we found that there are a total of 166 companies with incomplete data (less than 5 years annual report or listed background) will totally omit in our sample size.

Besides that, PN4 companies and PN17 companies are excluded in our sample. PN4 companies are those will subjected to trade restriction if it failed to comply with the original time frames prescribed under paragraph 5.0 of PN4 to regularize its financial condition and thus, they may be subjected to suspension from trading. PN17 companies are financially distressed company that require regularizing its condition under certain time frame, failing which the stock would be suspended from trading and face de-listing procedures. There are 18 of PN4 and PN17 companies excluded in our studies.

To investigate the matter even more accuracy, we then go on to deduct the companies consist of outlier which means their debt-to-equity is far from the average debt-to-equity ratio. In order to determine the outlier companies, we use the following equation:

$$
\begin{gathered}
\mu+/-(\sigma \times 3) \\
\mu=\text { mean, } \sigma=\text { standard deviation }
\end{gathered}
$$

The mean of debt-to-equity is 0.266 and standard deviation is 0.63037 . Hence, companies that have debt-to-equity higher than 2.1571 will be consider as outlier companies and there are 15 outlier companies shall be exclude in this study.

In conclude, listed companies eventually will be included in our sample size are a total of 381 companies.

\section{Analysis and Results}

In this chapter, we employed the linear regression model to conduct tests which are pooled regression model and cross sectional model.

From the results, the cross-sectional and pooled analysis results are consistent. Then, we conclude the results according to pooled regression model. First, the insider ownership does not affect to the firm capital structure. The result shows no relationship between the insider ownership and debt-to-equity ratio. Thus, we accept $\mathrm{H} 0$ for the Hypotheses I. This result is consistent with Huang and Song (2006) and contradicts with the research of Brailsford et al. (1999).

After we consider the firm size effect, the result shows this variable does influence the relationship between insider ownership and capital structure. There is significant relationship and insider ownership 
is positively correlated with debt-to-equity ratio. In other words, when there is higher insider ownership in small firm, it will cause to higher debt-to-equity. Hence, we reject $\mathrm{H} 0$ for Hypotheses II. It is consistent with the study of Bathala et al. (1994).

After conduct test to the industry control variable, the results shows the industry in which firms operate does influence the relationship between insider ownership and capital structure. It also affects the relationship between insider ownership and debt-to-equity ratio become positive correlated. As a result, we reject H0 for Hypotheses III. This result is consistent with Brailsford et al. (1999), Huang and Song (2006) and Wansley et al. (1996). The conclusion of the findings and recommendations will be delineated in the chapter five.

\section{Conclusion and Recommendation}

This research studies the effects of insider ownership on capital structure. Meanwhile, it investigates other variables which also influence the relationship between insider ownership and capital structure. This section summarizes the research results.

We used pooled regression model and cross sectional model to measure our outcomes. Generally, the pooled regression model showed that insider ownership does not affect the capital structure. After we consider the firm size and industry variable, the result show there is positive relationship between the insider ownership and capital structure. In other words, the degree of insider ownership would affect the financing decision, where the increasing of insider ownership would increase the total debt-to-equity in a firm when the firm size and industry variables moderate this relationship. Hence, firm size effect does influence the relationship between insider ownership and capital structure. The industry variable also does affect the relationship between insider ownership and capital structure.

A possible explanation can be applied to the insignificant relationship between insider ownership and capital structure is the bond market in Malaysian firms is in infant stage, which means not well developed. Huang and Song (2006) explained the China firms have low long-term debt ratio because the bond market is still in the infant stage of development. Malaysia market is facing the same situation as China market that the firms hold a low debt-to-equity ratio. This condition was occurred in developing countries. Most of the firms in Malaysia tend to rely on equity financing rather than issuing bond that serves as a long term liability to the company. There are fewer companies that issue bonds to finance their assets. In order to provide more financing opportunities for Malaysian firms, it is desirable for Malaysia to accelerate the development of its bond market. Another possible explanation is the fact that the influence of insiders in Malaysian companies is not so significant to affect the financing decision of a company. In Malaysia, listed companies are prone to borrow short term debt rather than long term debt. It is probably associated to the interest rate that offered by banks for long term borrowing is not as attractive as short term borrowing.

Despite the insignificant relationship, firm size, however, will moderate the relationship to become significant. The level of influence of insider ownership on capital structure in a firm varies according to 
firm size. In this study, the firm size is negatively correlated with the insider ownership and positively correlated with debt-to-equity ratio. In Huang and Song (2006) study, they explain this relationship is caused by the asymmetric information problem between insiders and outsiders. In order to reduce the agency cost, debt financing should be used. Hence, large firms with lower insider ownership prefer to have higher debt financing in order to reduce the agency cost. Another reason which can explain the relationship by Marsh (1982) is large firms would take advantage of the economies of scale in issuing long-term debt. Large firms have higher bargaining power with the creditors and there are able to obtain cheaper source of funds. Therefore, larger firms have higher debt-to-equity ratio. This concludes that the size of a firm has a very significant influence in the relationship between insider ownership and capital structure.

Another control variable, which is industry factor, does influence the relationship between insider ownership and capital structure. According to the studies of Brailsford, Oliver and Pua (1999), Huang and Song (2006) and Wansley, Collins and Dutta (1996), the possible explanation to this result is the firms in the same industry face similar demand and supply conditions and thus there have similar risk characteristic. Leverage ratios vary from different industry. In Wansley, Collins and Dutta (1996), Construction sector has the highest level insider ownership as compare to other industry. In this study, the findings show the same result which Construction Sector has the highest insider ownership among other industries. Thus, different industries would have different insider ownership level and debt level due to the different characteristic of the sector.

In addition, both study in Bathala et al. (1994) and Brailsford et al. (1999) explained that insider ownership is positive relationship with debt level due to the personal wealth constraint of corporate insiders. In a large firm, managers face difficulty to own larger stake of shares because managers have limited borrowing from company. Therefore as the size of the firm grow, it become more costly for managers to purchase the shares. As a result, fewer shares are hold by the managers and resulted insider control in a large firm become lower. The lower proportion of insider ownership in large firm affects shareholders have preference in making equity financing decision. Furthermore, the negative relationship of firm size on insider control can be seen through the concentrated and focused operations in small firm which give managers greater control over the firm. Thus, higher insider control in small firm would issue debt to avoid the dilution of voting right and the power of ownership. In conclude, firm size play an important role to affect the relationship between insider ownership and capital structure.

\section{References}

Bathala, C. T., Moon, K. P., \& Rao, R. P. (1994). Managerial Ownership, Debt Policy, and the Impact of Institutional Holdings: An Agency Perspective. Financial Management, 23(3), 38-50. https://doi.org/10.2307/3665620

Brailsford, T. J., Oliver, B. R., \& Pua, S. L. H. (1999). Theory and Evidence on the Relationship 
Structure and Capital Structure. Retrieved April 30, 2008, from http://www.ssrn.stanford.edu/delivery.php?ID=32200508302208609201412312107012502800708 1023074004060009020096127017101019091069000121112019070005084029036022065099105 008069029110108095012\&EXT=pdf

Bursa Malaysia Main Board Listed Companies. (2003-2007). Annual report. Kuala Lumpur, Wilayah Persekutuan.

Driffield, N., Mahambare, V., \& Pal, S. (2006). How Ownership Structure Affects Capital Structure and Firm Performance? Recent Evidence from East Asia. Journal of Economic Literature.

Huang, S. G. H., \& Song, F. (2006). The Determinants of Capital Structure: Evidence from China. China Economic Review, 17, 14-36. https://doi.org/10.1016/j.chieco.2005.02.007

Jensen, M., \& Meckling, W. (1976). The Theory of the Firm: Managerial Behaviour, Agency Costs, and Ownership Structure. Journal of Financial Economics, 3, 305-360. https://doi.org/10.1016/0304-405X(76)90026-X

Kleiman, R. T. (2006). Agency Theory. Retrieved March 10, 2008, from http://www.referenceforbusiness.com/encyclopedia/A-Ar/Agency-Theory.html

Marsh, P. (1982). The Choice Between Equity And Debt: An Empirical Study. The Journal of Finance, 37, 121-144. https://doi.org/10.1111/j.1540-6261.1982.tb01099.x

Phani, B. V., Reddy, V. N., Ramachandran, N., \& Bhattacharyya, A. K. (2002). Insider Ownership, Corporate Governance and Corporate Performance. NSE Research Initiative Proposal, 89.

Teall, J. L. (2007). Governance and the Market for Corporate Control (1st ed.). New York: Routledge.

Tse, C. B., \& Jia, J. Y. (2007). The Impacts of Corporate Ownership Structure on Incentive of Using Capital Structure to Signal. Studies in Economics and Finance, 24(2), 156-181. https://doi.org/10.1108/10867370710756192

Wansley, J. W., Collins, M. C., \& Dutta, A. S. (1996). Further Evidence on the Relation between Corporate Ownership Structure and Debt Policy. Managerial Finance, 22(2), 56-75. https://doi.org/10.1108/eb018549 